\title{
VERBA PULL DALAM NOVEL PS I LOVE YOU KARYA CECELIA AHERN DAN TERJEMAHANNYA: KAJIAN SINTAKSIS DAN SEMANTIS
}

\author{
Dwinesa Anggraeni \\ Universitas Indraprasta PGRI \\ Pos-el: dwinesaanggraeni@yahoo.co.id \\ Hp: 08561996743
}

\begin{abstract}
ABSTRAK
Penelitian ini berjudul Verba Pulldalam Novel P.S I Love Youkarya Cecelia Ahern dan Terjemahannya: Kajian Sintaksis dan Semantis. Novel ini dialihbahasakan ke dalam bahasa Indonesia oleh Monica Dwi Chresnayani dengan judul yang sama. Dari segi sintaksis, tujuan penelitian ini adalah untuk mengetahui unsur-unsur apa saja yang mengikuti verba pull dan apakah terjadi pergeseran sintaksis dalam terjemahannya. Dalam segi semantisnya adalah untuk mengetahui bagaimana penerjemahan verba pull dan apakah ada pergeseran makna dalam penggunaan verba tersebut dalam terjemahannya. Metode penelitian yang digunakan dalam penelitianini adalah metode deskriptifkomparatif.Deskripsi analisis untuk menggambarkan, membandingkan, dan menganalisis data dalam bahasa sumber dengan hasil terjemahannya, kemudian menarik simpulan dari analisis yang telah dilakukan. Hasil penelitian secara sintaksis menunjukkan bahwa verba pull dapat diikuti beberapa unsur yang berbeda-beda seperti verba pull+objek, pull+preposisi, pull+partikel adverbia.Secara semantis ditemukan pergeseran makna dalam penerjemahannya seperti perluasan makna dan penambahan makna.Selain itu, juga ditemukan beberapa kata yang tidak diterjemahkan kata per kata lagi, tetapi ditemukan bentuk kombinasi kata yaitu verba pull+adverbial particles yang disebut phrasal verbs.
\end{abstract}

Katakunci: verba, novel, penerjemahan, sintaksis, semantis.

\begin{abstract}
ABSTRCT
This research is entitled Verba Pull dalam novel PS I love You Karya Cecilia Ahern dan Terjemahannya: Kajian Sintaksis dan Semantis. This novel has been translated by Monica Dwi Chresnayani into Indonesian with the same title. Syntactically, the aims of the research are to find out what elements that follow that follow the verb 'Pull' and whether there is syntactic shift in the target language. While semantically, it is to find out the verb 'pull' translation and whether there is semantics shift from the source language into the target language. The method which is used in this research is descriptive-comparative method. The writer describes, compares, and analyzes the source language and the target language data, and then draws a conclusion from the analyses. Syntactically, the result of this research shows that the verb 'pull' can be followed by some different elements such as pull + object, pull + Preposition, pull+adverbial particle. Then, semantically, it is found some meaning shift in the translation like the expansion meaning and enhancing meaning. In the translation, the writer also find some words that are not translated word by word but make a word combination, the verb 'pull' + adverbial particles its called phrasal verbs.
\end{abstract}

Key words: verb, novel, translation, syntactic, semantic 


\section{PENDAHULUAN \\ Latar Belakang}

Bahasa dapat dikatakan sebagai salah satu alat penting dalam berkomunikasi oleh manusia yang dasarnya adalah makhluk sosial. Manusia menggunakan bahasa untuk mengekpresikan segala bentuk perasaannya dalam lingkungan sosialnya.Telah kita ketahui, setiap bangsa memiliki bahasa yang berbeda-beda.Saat ini, bahasa asing terutama bahasa Inggris mulai banyak digunakan di berbagai fasilitas umum yang ada disekitar kita.Banyak informasi-informasi yang dituliskan dalam bahasa Inggris. Oleh karena itu, penerjemahan tidak dapat dipisahkan dari bahasa dan merupakan faktor penting dalam proses berkomunikasi.

Dalam menerjemahkan, seorang penerjemah dituntut untuk mengetahui struktur, bentuk, dan fungsi unsur-unsur dasar yang berlaku dalam bahasa tersebut.Hal ini dilakukan untuk menghindari kesalahan dalam menerjemahkan agar pesan dapat tersampaikan dengan baik dan benar. Kadang penerjemah menemukan beberapa kesulitan dalam menerjemahkan teks bahasa sumber, seperti teks bahasa Inggris ke dalam bahasa Indonesia terutama dalam menemukan padanan yang sesuai. Kesalahan penerjemahan sulit dihindari, tetapi setidaknya penerjemah dapat mengurangi kesalahan tersebut dengan mengetahui dan memahami unsur-unsur dalam tata bahasa Inggris.Salah satu unsur penyusun bahasa dalam tata bahasa Inggris adalah verba.

Verba adalah salah satu unsur paling penting dalam pembentukan sebuah kalimat.Verba dalam bahasa Inggris memiliki berbagai macam fungsi, struktur, dan makna.Ada verba yang berdiri sendiri (intransitive verbs) adapula yang membutuhkan objek (transitive verbs) sebagai pelengkap kalimatnya. Ada verba yang diikuti preposisi yakni keduanya behubungan secara sintaksis dan semantik seperti divorce from,decide on, dan disappointed with. Adapula verba yang bergabung dengan partikel adverbial yang akan menimbulkan makna baru berbeda dengan makna individualnya seperti pull back (menarik mundur pasukan), pull over (menepi), dan pull through (sembuh). Adanya perbedaan struktur verba dalam tata bahasa Inggris mempengaruhi struktur kalimat dalam bahasa sasaran yaitu bahasa Indonesia.Hal ini membuat adanya pergeseran sintaksis dan semantis dalam penerjemahan.Selain itu, terjemahan dapat dipengaruhi pula oleh unsur-unsur yang mengikuti verba tersebut.

Sehubungan dengan itu, penulis ingin meneliti lebih jauh mengenai verba pull dalam kajian sintaksis dan semantis, dengan mengambil judul Verba Pulldalam Novel PS I Love You karya Cecelia Ahern dan Terjemahannya: Kajian Sintaksis dan Semantis.

\section{Rumusan Masalah}

Permasalahan yang dianalisis dalam penelitian ini adalah sebagai berikut.

1. Unsur apa saja yag mengikuti verba pull dalam novel PS I Love You? 
2. Apakah terjadi pergeseran sintaksis pada verba pull dalam bahasa sasarannya?

3. Apakah terjadi pergeseran semantis pada verba pull dalam bahasa sasaranya?

\section{Tujuan Penelitian}

Penelitian ii dilakukan unguk tujuan berikut.

1. Mendeskripsikan unsur apa saja yang mengikuti verba pull.

2. Mendeskripsikan pergeseran sintaksis verba pull dari penerjemahan bahasa sumber.

3. Mendeskripsikan pergeseran semantis verba pull dalam bahasa terjemahan.

\section{Kegunaan Penelitian}

Secara teoretis, penelitian ini dapat memberikan data secara empiris dalam kajian sintaksis dan semantis.Selain itu, dapat memberikan masukan bagi perkembangan ilmu bahasa.Selain itu, hasilnya dapat digunakan sebagai dokumentasi atau contoh penelitian bagi pihak-pihak yang memerlukan.

Secara praktis,penelitian ini memberikan manfaat bagi penulis untuk mengetahui secara mendalam mengenai verba pull dalam kajian sintaksis dan semantis baik yang terdapat pada bahasa sumber maupun sasaran.

\section{Kerangka Penelitian}

Awal ketertarikan penulis terhadap penelitian ini dimulai dengan pemilihan sumber data yang penulis gunakan yaitu novel PS I Love You karya Cecelia Ahern dan terjemahannya. Dalam novel tersebut penulis menemukan beberapa data mengenai bentuk verba pull yang diikuti dengan unsur-unsur yang berbeda. Selain itu, penulis menemukan adanya beberapa pergeseran sintaksis dan semantis dari bahasa sumber ke dalam bahasa sasaran.Penulis tertarik menerjemahkan novel ini karena jalan cerita novel tersebut sangat menarik dan menyentuh. Hal-hal tersebut yang bagi penulis novel PS I Love You karya Cecilia Ahern dan terjemahannya sebagai objek penelitian.

\section{KAJIAN TEORI}

\section{Sintaksis}

Sintaksis adalah suatu bidang linguistik yang mempelajari bagaimana sekelompok kata disusun menjadi sebuah kalimat, klausa, atau frasa.Singkatnya sintaksis mempelajari susunan kata-kata di dalam kalimat.Bidang ilmu sintaksis menyelidiki semua hubungan antara kata dan antarkelompok kata (antarfrasa) dalam satuan dasar sintaksis.Asal mula kata sintaksis berasal dari bahasa Yunani, sun 'dengan' dan tettein 'menempatkan' dan 
dalam bahasa Inggris disebut syntax.Secara etimologis sintaksis berarti menempatkan bersama-sama kata-kata menjadi sekelompok kata dan antarkelompok kata atau kalimat dan kelompok-kelompok kata menjadi kalimat.

Menurut John, Yates, dan Laney (1982: 319) sintaksis adalah "The communication of meaning through the order of the words in a sentence."Pada dasarnya sintaksis mengkaji hubungan antarkata di dalam kalimat.Hubungan antarkalimat termasuk "analisis wacana" dan hubungan antar tata bahasa kalimat menurut kajian sintaksis.

Dengan demikian dapat disimpulkan bahwa sintaksis adalah cabang dari ilmu linguistik yang berusaha menjelaskan dan menerangkan mengaenai analisis wacana, kalimat, klausa, frase, kata serta hubungan antar unsur-unsur satuan sintaksis itu dalam suatu ujaran, baik hubungan yang bersifat fungsional maupun hubungan yang bersifat manusiawi.

\section{Unsur Sintaksis}

\section{Kata}

Bloomfield (1933: 178) berpendapat bahwa "The word is the minimum free form, the smallest form that may occur in isolation." Seperti yang dijelaskan oleh Aronoff dan fudeman (2005: 34) "A word is the smallest unit of the language that can stand alone" atau unit terkecil dalam kajian sintaksis.

Jadi, menurut definisi di atas dapat dijelaskan kata adalah satuan bahasa terkecil yang dapat berdiri sendiri atas satu morfem atau lebih, dan dapat muncul dalam ujaran.

\section{Frasa}

Pemberton(1993: 173) berpendapat bahwa "A phrase is a group of words putting together as a unit, having neither subject nor verb." Verhaar (1999: 291) berpendapat "Frasa dapat dikatakan sebagai kelompok kata yang merupakan bagian fungsional dari tuturan (kalimat) yang lebih panjang." Frasa adalah bagian fungsional, maksudnya adalah bagian ini berfungsi sebagai konstituen di dalam konstituen yang lebih panjang. Dengan kata lain frasa adalah pengisi fungsi sintaksis, baik berupa subjek, predikat, objek, ataupun keterangan, yang biasanya terdiri atas dua kata atau lebih yakni hubungan antardua kata itu dapat diperluas.

Paparan di atas dapat disimpulkan bahwa frasa adalah konstituen pengisi fungsifungsi sintaksis, baik berupa subjek, predikat, objek, atau keterangan, yang biasanya terdiri atas dua kata atau lebih yakni hubungan antarkatanya cukup longaar dan dapat diperluas. 


\section{Klausa}

John, Yates, dan Laney (1982: 326) "Clause is a group of words containing a subject and verb that is used as part of a larger sentence." Verhaar (1999: 162) Klausa yaitu kalimat yang terdiri atas hanya satu verba atau verba asal saja, disetai satu atau lebih konstituen (segmen yang merupakan satuan gramatikal) yang secara sintaksis berhubungan dengan verba tadi. Tarigan (1993) menambahkan "Klausa adalah kelompok kata yang mengandung satu predikat,"

Dari pendapat di atas dapat disimpulkan bahwa klausa adalah satuan gramatikal di atas frasa dan di bawah kalimat dan berupa kelompok kata yang terdiri atas satu objek dan predikat.

\section{Kalimat}

Kalimat adalah salah satu unsur yang terdapat dalam bidang sintaksis. Roberts (1964: 1) menyatakan "A sentence is a group of words expressing complete thought or a group of words that begin with capital letter and ends with a period." Deangan kata lain kalimat adalah satuan yang merupakan keseluruhan yang memiliki intonasi tertentu sebagai pemarkah keseluruhan itu, seperti dalam ortografi akhir kalimat dilambangkan dengan titik atau dengan tanda akhir lain yaitu tanda seru atau tanda tanya. Dapat dikatakan pula kalimat adalah sekumpulan kata yang diucapkan atau ditulis menurut sistem bahasa dari suatu bangsa atau sekelompok manusia yang memiliki aturan tertentu.Dapat ditambahkan kalimat merupakan satuan sintaksis yang disusun dari konstituen dasar yang berupa klausa, dilengkapi konjungsi bila diperlukan, serta dengan intonasi akhir.

Dapat disimpulkan bahwa, kalimat adalah satuan sintaksis yang secara non verbal tersusun dari satuan sintaksis lain yang lebih (dapat berupa kata, frasa, dan klausa) yang ditandai dengan intonasi akhir, sedangkan secara verbal kalimat adalah satuan bahasa yang digunakan oleh manusia sebagai satuan ujaran dalam komunikasi.

\section{Kelas Kata dalam Bahasa Inggris}

Kelas kata dalam bahasa Inggris dikenal dengan part of speech yang merupakan bagian sintaksis yang diklasifikasikan berdasarkan fungsinya dalam sebuah kalimat.House dan Harman (1950: 16) membagi kelas kata menjadi delapan kelompok yaitu nouns, verbs, adjectives, adverbs, prepositions, interjections, conjunctions, dan pronouns.Dalam penelitian ini, penulis hanya membatasijenis kelas kata yang berkaitan verba. 


\section{Verba}

John, Yates, dan Laney (1982: 328) berpendapat "Verbs are words that assert something about persons, things, or ideas by telling what they do or that they exist." Predikat itu biasanya berupa verbal yang artinya secara kategorial predikat itu berupa verba. Verba mempunyai fungsi penting dalam pembuatan sebuah kalimat karena ia adalah unsur terpenting dalam sebuah kalimat. Dapat dikatakan verba adalah suatu keadaan, kejadia, atau kegiatan yang di dalam kegiatan tersebut terlibatlah orang atau benda, satu atau lebih. Orang atau benda tersebut disebut "peserta-peserta" dalam keadaan dan kejadian yang diungkapkan dalam verba tersebut. Jumlah peserta tergantung dari jenis verba di tempat predikat.

Dari uraian di atas dapat disimpulkan bahwa verba selain dapat menggambarkan suatu perbuatan, keadaa, proses juga merupakan kelas kata terpenting yang mempunyai kemampuan memperlihatkan kala, aspek, dan fungsinya sebagai predikat.

\section{Semantik}

Istilah semantik berpadanan dengan kata semantique dalam bahasa Perancis yang diserap dari bahasa Yunani. Istilah dalam bahasa Inggris adalah semantics yang diambil dari bahasa Yunani sema (kata benda) yang artinya 'sign' atau semanio (kata kerja) yaitu 'to signify' atau memakai. Lehrer (1974

: 1) menyatakan bahwa "Semantik adalah ilmu mengenai makna."

O'Grady (1997: 268) berpendapat bahwa "Semantic is the study of meaning in human language." Dengan kata lain semantik adalah ilmu yang mempelajari makna dalam suat bahasa. (Encyclopedia Britanica, Vol 201965: 313) menerjemahkan "Semantik sebagai studi tentang hubungan antara suatu pembeda linguistik dengan hubungan proses mental atau simbol dalam aktivitas bicara."

Jadi dapat disimpulkan semantik adalah ilmu dalam suatu bahasa atau bahasa pada umumnya dengan objek studi makna-makna dalam tataran gramatikal.

\section{Hakikat Makna}

Menurut Lyons (1981: 136) "Meanings are ideas or concepts which can be transferred from the mind of the hearer by embodying as it were, in the form of one language or another." Saussure (1857: 1913) dalam teori tanda lingistiknya menyatakan setiap tanda bahasa terdiri atas dua komponen yaitu komponen signifian atau "yang mengartikan" yang wujudnya berupa runtutan bunyi dan signifie atau "yang diartikan" yang wujudnya pengertian atau konsep. Dengan demikian, teori yang dikembangkan oleh Saussure menyatakan bahwa "Makna adalah pengertian atau konsep yang dimiliki atau terdapat pada sebuah tanda linguistik." 
Jadi, dapat disimpulkan bahwa makna dapat diketahui dari tulisan, pembicaraan, mendengar sesuatu, atau membaca lambang-lambang berdasarkan sistem bahasa tertentu.

\section{Jenis Makna}

\section{Makna Leksikal, Gramatikal, dan Kontekstual}

Makna leksikal dapat disebut makna yang ada dalam kamus yaitu makna yang lepas dari penggunaan atau konteksnya. Richard, et al. (1985: 61) mnyatakan bahwa "Lexical meaning contains words which refer to a thing, quality, state, or action and which have meaning when the words are used alone."

Menurut Chaer (2003: 290) "Makna leksikal berbeda dengan makna gramatikal, makna gramatikal baru ada jika ada terjadi proses gramatikal, seperti afiksasi, reduplikasi, komposisi, atau kalimatisasi.'Dalam hal yang samaRichard et al. (1985: 61) berpendapat bahwa "Gramatical meaning contains words which have little meaning on their own, but which show grammatical meaning in and between sentences." Dapat dikatakan makna gramatikal adalah makna yang berhubungan dengan makna kata yang terkandung dalam kata tersebut.

Menurut Chaer (2003: 290) "Makna kontekstual adalah makna sebuah leksem atau kata yang berada dalam satu konteks." Dengan kata lain, makna kontekstual ialah makna yang dikaitkan dengan situasi pengguna bahasa.

\section{Makna Verba Pull}

Menurut Hornby (2000: 1067) makna verba pull dapat dikelompokkan menjadi dua kelompok:

1. Verba pull yang dapat berdiri sendiri (tidak berpartikel) memiliki makna:

a. To hold something firmly and use force in order to move it towards yourself. Contoh; don't pill so hard or the handle will come off.

b. To hold or be attached to something and move it along behind you. Contoh; in this area oxen are use to pull charts.

c. To open or close curtains, etc. Contoh; pull the curtains. It's dark outside.

d. To move somebody/ something in a particular direction by pulling. Contoh; pull your chair nearer the table.

e. To damage a muscle, etc. by using too much force. Contoh; to pull a muscle.

f. To move a switch, etc. towards yourself or down in order to operate a machine or piece of equipment. Contoh; don't pull the trigger! 
g. To move or make vehicle move sideways.

Contoh; she pulled the car to the right to avoid the dog.

$h$. To attract the interest or support of somebody or something.

Contoh; they pulled in huge crowds on their latest tour,

i. To attract somebody sexually.

Contoh; he can still pull the girls.

j. $\quad$ To succeed in playing a trick on somebody, committing a crime, etc.

Contoh; he is pulling some short of trick on you.

$k$. To cancel an event, to shop showing an advertisement, etc.

Contoh; the gig was pulled at its last moment.

2. Verba pull yang diikuti partikel adverbia yaitu yang membentuk frasa verba memiliki maknaseperti berikut.

a.Pull a head of $(\mathrm{sb} / \mathrm{sth})=$ to move in front of $\mathrm{sb} / \mathrm{sth}$.

b. Pull something apart $=$ to separate something into pieces by pulling different parts of it in different direction.

c. Pull away (from something) $=$ (of a vehicle) to start moving.

d. Pull back (of an army) = to move back from a place, to decide not to do sth that you were intending to do because of possible problems.

e. Pull (sth) down = to destroy a building completely.

f. Pull off $($ sth $)=$ (of a vehicle or its driver) to leave the road in order to stop for a short time.

g. Pull over (of a vehicle or its driver) = to move to the side of the road in order to let sth pass.

h. Pull though $($ sth $)=$ to get better after serious illness, operation etc.

$i$. Pull together $=$ to act, work, etc. together with other people in an organized way and without fighting.

j. $\quad$ Pull up (of a vehicle or its driver) = to stop.

k. Pull out $=$ (of a vehicle or its driver) to move away from the side of the road.

l. Pull sb/sth out = to make sb/sth move away from sth or stop being involved in it.

\section{Penerjemahan}

Menurut Catford (1993: 3) penerjemahan adalah "Translation is the replacement of textual material in one language (source of language) by equivalent textual material in another language (target language)." Dengan kata lain, penerjemahan adalah suatu proses penggantian suatu teks bahasa sumber ke bahasa sasaran. 


\section{Jenis Penerjemahan}

\section{Penerjemahan Kata demi Kata (word-for word translation)}

Nababan (1999: 30) berpendapat penerjemahan kata demi kata adalah suatu jenis penerjemahan yang pada dasarnya masih sangat terikat pada tataran kata. Penerjemahan tipe ini bisa diterapkan hanya jika bahasa sumber dan bahasa sasaran mempunyai struktur yang sama.

- Jim gave me two tickets yesterday

(Jim memberi saya dua tiket kemarin)

\section{Penerjemahan Bebas (free translation)}

Nababan berpendapat (1999: 31) penerjemahan bebas sering tidak terikat pada pencarian padanan kalimat, tetapi pecarian padanan itu cenderung terjadi pada tataran paragrap atau wacana.Penerjemahan ini terjadi karena bahasa sumbernya sedemikian rumit sehingga satu kalimat bahasa sumber dapat mengandung pesan yang panjang dan memerlukan beberapa kalimat padanannya.

(1)To play truant (membolos).

(2) To kick something around (membahas).

Killing two birds with one stone (sambil menyelam minum air).

3. Penerjemahan Harfiah (literal translation)

Nababan (1999: 32) jenis penerjemahan ini menyesuaikan susunan kata dalam kalimat terjemahannya yang sesuai dengan susunan kata dalam kalimat bahasa sasaran. Penerjemahan harfiah ini biasannya dimulai dengan penerjemahan kata demi kata, sehingga penerjemahan harfiah hampir sama dengan penerjemahan kata demi kata. Oleh karena itu, kadangkala pesan yang terkandung did lam bahsa sumbernya teralihkan atau bahkan berubah sama sekali dan tak jarang membingunkan.

(1) Bahasa sumber: How are you?

(2) Bahasa sasaran: Bagaiman ada(lah) Anda?

(Terjemahan kata demi kata)

Bagaimana keadaan anda?

(Terjemahan harfiah)

Apa kabar?

(Terjemahan bebas) 


\section{Pergeseran dalam Penerjemahan}

Pergeseran merupakan hal yang tidak dapat dipisahkan dalam penerjemahan.Catford (1965: 73) berpendapat pergeseran adalah "Departures from formal correspondence in the process of going from the SL to the TL."

Catford juga membagi pergeseran menjadi dua macam:

\section{Level Shift (Pergeseran Tataran)}

Menurut Catford (1965: 73) menyatakan bahwa "By a shift of level we mean that a SL (source language) item at one linguistic level has a TL (target language) translation equivalent at a different level." Jadi pergeseran tataran terjadi apabila suatu istilah bahasa sumber dalam satu tingkatam bahasa memiliki padanan terjemahan dalam tingkatan yang berbeda.

\section{Category Shift (pergeseran kategorial)}

Menurut Catford (1965: 73) menyatakan bahwa pergeseran katagori terdiri dari empat tingkatan:

a. Pertama, Structure Shift (Pergeseran Struktur). It is the most common form of shift and to inform mostly a shift in grammatical structure. Pergeseran struktur dalam terjemahan bahasa Inggris ke dalam bahasa Indonesia bisa terjadi dalam struktur kalimat, klausa, frasa, dan perubahan kalimat aktif menjadi pasif ataupun sebaliknya.

Contoh pergeseran struktur yang terjadi pada frasa

Bahasa Sumber (Source Language): Black Roses

Bahasa Sasaran (Target Language): Mawar Hitam

Dalam tataran bahasa Indonesia, setiap frasa memiliki bagian inti dan bagian yang memperluasnya.Bagian inti disebuat bagian yang diterangkan (D) dan bagian yang memperluasnya disebut bagian yang menerangkan (M).pada contoh di atas, frasa TL memeliki hubungan MD dalam bahasa Inggris, tetapi dalam SL pola tersebut mengalami pergeseran pola DM.

b. Kedua, Class Shift (Pergeseran Kelas) pergeseran ini dapat berupa pergeseran terjemahan dari nomina menjadi ajektiva, merba menjadi nomina, atau lainnya.

Contoh: Bahasa Sumber (Source Language): delightful

Bahasa Sasaran (Target Language): menyenangkan

Pada contoh di atas kata delightful memiliki kelas kata ajektiva dan memngalami pergeseran kelas kata menyenangkan yang memiliki kelas kata verba.

c. Ketiga, Unit Shift (Pergeseran Unit) pergeseran ini dapat terjadi dari kata menjadi frasa.

Contoh: Bahasa Sumber :There's a wonderful place in London. 
Bahasa Sasaran: Di London ada suatu tempat yang bagus sekali.

Pada contoh di atas terjadi pergeseran unit dari kata ajektiva wonderful yang diterjemahkan menjadi frasa ajektiva bagus sekali.

d. Keempat, Intra-System Shift yaitu pergeseran intra sistem

Contoh pada nomina, denngan adanya sitem tunggal dan jamak.Perubahan sufiks $-s$ atau es pada nomina yang menandai bentuk jamak dalam bahasa Inggris tidak selalu diterjemahkan dengan pengulangan nomina yang menandai kejamakan dalam bahasa Indonesia. Contoh kata books diterjemahkan menjadi buku-buku tanpa pengulangan nomina karna kejamakannya sudah implicit. Dengangkan kata-kata seperti glasses diterjemahkan menjadi kaca mata, scissors diterjemahkan menjadi gunting tidak terjadi pengukangan nomina dalam bahasa Indonesia.

Menurut Newmark (1988: 85--87) yang dimaksud dengan pergeseran adalah sebagai berikut.

1. The change from singular to plural or in the position of the adjective.

2. Shift is required when a SL grammatical structure doesn't exist in the TL.

3. Shift is the one where literal translation is grammatically possible, but may not accord with natural usage in the TL.

4. Shift is the replacement for the virtual lexical gap by a grammatical structure.

Berdasarkan kedua teori tersebut dapat ditarik kesimpulan pergesran terjemahan terbagi seperti berikut.

1. Pergeseran Struktur

Pergeseran struktur adalah pergeseran yang berhubungan dengan struktur dalam bahasa sumber dan bahasa sasaran.Contohnya adalah perubahan kalimat ktif menjadi kalimat pasif atau sebaliknya.

SL: "He heard a sound in the air."

TL: "Terdengar suara di udara."

2. Pergeseran kategorial

Pergeseran katagorial adalah pergeseran dalam kelas kata dalam bahasa sumber ke bahasa sasaran.

SL: "All the taxes will be responsibility of the buyer."

TL: "Semua pajak akan ditanggung pembeli."

3. Pergeseran Tataran

Pergeseran tataran adalah pergeseran yang menyangkut hubungan kalimat, klausa, frase, dan kata.

SL: "The boat rocked gently on the water, the ripples slapping softly against the prow." 
TL: "Perahu itu bergoyang lembut diatas air riak, air memukul-mukul haluan perahu dengan halus."

Pada kalimat dalam bahasa softly merupakan adverbial dalam bentuk satu kata.Akan tetapi, dalam bahasa sasaran kata tersebut diterjemahkan menjadi adverbial berbentuk frasa.Hal tersebut merupakan suatu pergeseran tataran dari kata menjadi frasa.

4. Pergeseran Semantis

Pergeseran semantis adalah pergeseran yang berhubungan dengan makna.Pergeseran ini dilakukan agar pesan yang ingin disampaikan dalam bahasa sumber ke bahasa sasaran dapat tersampaikan dengan baik dan benar.Pergeseran semantis terbagi menjadi seperti berikut.

a. Perluasan makna yaitu penyerapan unsur-unsur kosakata ke dalam bahasa lainnya. Contohnya teknologi yang berasal dari bahasa Inggris yang telah menambah kosa kata dalam bahasa Indonesia. Menurut Chaer (1994: 141) "Perubahan makna meluas adalah gejala yang terjadi pada sebuah kata yang mulanya hanya memiliki sebuah makna, tetapi karena berbagai faktor maka memiliki makna lain."

Contohnya: Saudara saya hanya dua orang.

Surat Saudara sudah saya terima.

Saudara-saudara setanah air marilah kita

mengheningkan cipta.

b. Penambahan makna yaitu penambahan kosakata baru dengan makna yang agak khusus meskipun kosakata lama masih tetap dipergunakan dan bermakna lengkap. Contohnya kata kitab yang berasal dari bahasa Arab yanag memiliki makna buku bacaan, memiliki makna khusus yaitu wahyu Tuhan yang dibukukan.Chaer (1994: 141) menyebut penambahan makna dengan penyempitan makna yaitu "Gejala yang terjadi pada sebuah kata yang pada mulanya mempunyi makna yang cukup luas, kemudian terbatas hanya pada satu buah makna saja."

Contoh: Penyanyi itu adalah seorang ahli bedah.

Seorang ahli pubakala biasanya dikenal dengan sebutan arkeolog.

c. Penggantian makna yaitu penggantian kosakata yang disebabkan adanya perubahan makna. Contoh kata saya adalah perubahan dari kata bahasa Melayu Lama yaitusahaya. Chaer (1994: 141) menyebutnya perubahan total yaitu "Suatau keadaan dimana berubahnya sama sekali makna sebuah kata dari makna asalnya." 


\section{METODE PENELITIAN}

Dalam penelitian ini, penulis menggunakan metode deskriptifkomparatif. Djajasudarma (2006: 9) berpendapat bahwa "Metode deskriptif adalah metode yang bertujuan memuat deskripsi; maksudnya membuat gambaran, lukisan secara sistematis, faktual dan akurat mengenai data, sifat-sifat serta hubungan fenomena-fenomena yang diteliti".Sementara itu, menurut Hadi (2004) metode komparatif adalah "Suatu analisis yang harus menggunakan dua kasus atau dua kelompok kasus".Dalam hal ini penulis menentukan bahan penelitiaan dengan membaca novel aslinya terlebih dahulu kemudian dilanjutkan dengan terjemahannya. Kemudian penulis mengumpulkan data mengenai verba pull dalam novel tersebut selanjunya diklasifikasikan berdasarkan unsur yang mengikutinya. Kemudian data tersebut dianalisis berdasarkan teori-teori yang berkaitan dengan data yang dikumpulkan dengan proses sintaksis dan semantisnya. Untuk memperoleh data yang memadai dan berkaitan dengan permasalahan dalam skripsi ini, penulis menggunakan beberapa sumber buku yang membahas verba dengan menggunakan studi pustaka.

\section{Lokasi dan Waktu Penelitian}

Penelitian yang penulis lakukan bersifat studi pustaka yaitu teknik pengumpulan data yang digunakan penulis dengan cara mempelajari masalah, mencari teori-teori yang sesuai dengan kajian penulis, dan mencari pemahamannya. Penulis menggunakan bukubuku dan kamus dalam membantu penyusunan skripsi ini, sehingga penelitian ini tidak mengacu pada lokasi-lokasi tertentu.Penulis melakukan penelitian ini dari bulan November 2015.

\section{Objek Penelitian}

Objek penelitian ini adalah novel yang berjudul ini P S I Love You yang ditulis oleh Cecelia Ahern.Novel ini diterbitkan pertama kali pada bulang April 2004 di Irlandia dengan penerbit Thorndike Publisher. Penulis juga menggunakan novel terjemahannya yang mempunyai judul sama dengan novel aslinya, diterjemahkan oleh Monica Dwi Chresnayani. Novel ini dicetak pertama kali pada Agustus 2005 dengan penerbit PT Gramedia Pustaka Utama.

\section{Teknik Pengumpulan Data}

Dalam penelitian ini penulis melakukan pengumpulan data dengan beberapa langkah. Langkah-langkah tersebut penulis gunakan untuk memudahkan menyusun setiap detail cara 
yang erapkan dalam proses penganalisisan data. Langkah-langkah tersebut adalah sebagai berikut.

\section{Observasi Data}

Pertama-tama penulis melakukan langkah awal yaitu membaca novel P.S. I Love You karya Cecelia Ahern dari bahasa sumbernya yaitu bahasa Inggris. Kemudian, penulis membaca novel terjemahannya dalam bahasa Indonesia sebagai bahasa sasarannya. Ketika membaca, penulis mendapatkan data deskriptif berupa kata-kata tertulis dari isi cerita novel tersebut dan mulai merumuskan masalah apa yang akan diteliti. Dalam langkah ini, penulis menentukan masalah dan menetapkan verba pull sebagai pokok permasalahan yang akan ditinjau dari segi sistaksis dan semantis. Setelah membaca, penulis dapat merumuskan masalah-masalah apa saja yang akan dianalisis dari verba pull.

\section{Pengklasifikasian Data}

Dalam pengklasifikasian data ini, penulis mencari kalimat-kalimat yang mengandung penggunaan verba pull dalam novel berbahasa Inggris. Kemudian verba tersebut dikelompokkan meurut strukturnya seperti verba pull yang diikuti oleh unsur-unsur tertentu. Penulis mengklasifikasi verba pull + objek, verba pull + preposisi, verba pull + partikel adverbia. Jadi penulis mengklasifikasi data-data dalam novel menurut unsur-unsur yang mengikuti verba pull tersebut.

\section{Penganalisaan Data}

Pengklasifikasian data berdasarkan unsur-unsur tersebut diatas yang telah dikelompokkan. Langkah selanjutnya adalah penganalisaan data dan dijelaskan berdasarkan unsur apa saja yang mengikutinya. Dalam kajian sintaksis penulis menganalisis apakah verba pull dalam novel asli mengalami pergeseran secara satuan atau secara kategori atau struktur. Kemudian, penulis menganalisis apakah verba pull mengalami perubahan bentuk strukturnya ketika menggunakan kata tertentu. Setelah itu, penulis menganalisis semantis verba pull dalam bahasa sumber dan bahasa sasarannya.

\section{HASIL DAN PEMBAHASAN}

\section{Verba Pull + Objek}

1a: holly pulled the key from the door and searched through the bunch for the correct one. (PSILY: Chapter 24 page 146)

1b: Holly mencabut kunci itu dan mencari-cari yang tepat dari serencengan anak kunci yang dibawanya. (PSILYT Chapter 24 page 283) 
Analisis:

Secara sintaksis, verba pull 1a pada data diatas merupakan bentuk past tense. Past tense digunakan utnuk menyatakan suatu perbuatan yang terjadi pada waktu lampau. Verba pull adalah kata kerja beraturan sehingga bentuk lampaunya hanya ditambah -ed. Kalimat 1a diatas terdiri atas dua klausa dan verba pull terdapat pada klausa pertama. Verba pull pada 1a diatas adalah bentuk verba transitif karena memiliki objek berupa nomina yaitu the key. Jika dilihat dari bahasa sumber, verba pull merupakan verba dan diterjemahkan kembali menjadi mencabut yang merupakan verba dalam bahasa sasaran. Disini tidak terjadi pergeseran tataran karna pull dalam bahasa sumber dan sasaran, tetapi menjadi kata yang memiliki fungsi yang sama sebagai predikat.

Secara semantis makna leksikal verba pull 1a adalah "to hold something firmly and use force in order to move it toward yourself." Jika dilihat berdasarkan makna leksikalnya, makna terjemahan pull dapat berupa menarik, mencabut, memetik, menahan-nahan, mendaki, dan menyobek. Di sini penerjemahan menghasilkan makna leksikal yakni dalam bahasa sasaran verba pull diterjemahkan menjadi mencabut yang memiliki makna yang sama dengan makna kamus. Jadi, di sini tidak terjadi pergeseran makna dari bahasa sumber ke bahasa sasaran.

\section{Verba Pull + Preposisi}

1a: He look like he was choking underneath the tightness of his bow tie and he pulled at it, looking uncomfortable. (PSILY Chapter 46 page 293)

1b: dia tampak seperti tercekik dasi kupu-kupu yang membelit lehernya, da terus saja menarik-narik dasi itu, terlihat sangat tidak nyaman. (PSILYT Chapter 46 page 557)

Analisis :

Secara sintaksis, verba pull 1a pada data di atas merupakan verba bentuk past tense. Pasttense digunakan untuk menyatakan suatu perbuatan yang terjadi pada waktu lampau.Pull adalah kata kerja beraturan sehingga bentuk lampaunya hanya ditambah -ed. Kalimat 1a di atas terduru dari tiga klausa dan verba pull terdapat pada klausa ketiga. Verba pull 1a di atas adalah bentuk verba transitif karena memiliki objek berupa nomina yaitu it. Dalam kalimat 1a pull juga diikuti preposisi yaitu at yang mengacu pada ojeknya yaitu it. Jika dilihat dari bahasa sumber, verba pull merupakan verba dan diterjemahkan kembali menjadi menarik-narik yang merupakan verba pula dalam bahasa sasaran. Disini tidak terjadi pergeseran tataran karena pull dlam bahasa sumber dan sasaran tetap menjadi kata yang memiliki fungsi yang sama sebagai predikat.

Secara semantis makna leksikal verba pull 1a adalah "to hold something firmly and use force in order to move it toward yourself." Jika dilihat berdasarkan makna leksikalnya, makna terjemahan pull dapat berupa menarik, mencabut, memetik, menahan-nahan, mendaki, dan menyobek. Pull dalam kalimat 1a diikuti preposisi yaitu at yang apabila 
diterjemahkan perkata menjadi pull (menarik) at (pada) yang maknanya sama dengan menarik-narik pada. Disini penerjemahan menghasilkan makna leksikal.Dalam bahasa sasaran verba pull diterjemahkan menjadi menarik yang memiliki makna yang sama dengan makna kamus. Jadi, di sini tidak terjadi pergeseran makna dari bahasa sumber ke dalam bahasa sasaran.

2a: A feeling of dread pulled at her heart and she hopped she wasn't going to say what she thought she was about to say. (PSILY: Chapter 46 page 304)

2b: Hatinya diliputi perasaan takut dan dia berharap Daniel tidak akan mengatakan sesuatu yang sepertinya bisa diduga. (PSILYT: Chapter 46 page 576)

\section{Analisis:}

Secara sintaksis, verba pull 2a pada data diatas merupakan verba bentuk past tense. Past tene digunakan untuk menyatakan suatu perbuatan yang terjadi pada waktu lampau.Pulladalah kata kerja beraturan sehingga bentuk lampaunya hanya ditambah -ed. Kalimat 2aditas terdiri atasi lima klausa dan verba pull terdapat pada klausa pertama. Verba pull 2a di atas adalah bentuk verba transitif karena memiliki objek berupa nomina yaitu her heart. Di sini pull pada 2a jugadiikuti oleh preposisi yaitu at yang mengacu pada objeknya yaitu her heart. Jika dilihat dari bahasa sumber, verba pull merupakan verba dan diterjemahkan kembali menjadi diliputi dalam bahasa sassaran. Disini terjadi pergeseran struktur karena pull dalam bahasa sumber berbentuk aktif sedangkan dalam bahasa sasaran berbentuk pasif.

Secara semantis makna leksikal verba pull 2a adalah "to move somebody/something in a particular direction by pulling." Jika dilihat berdasarkan makna leksikalnya, makna terjemahan pull dapat berupa menarik, mencabut, memetik, menahan-nahan, mendaki, dan menyobek. Di sini penerjemah melakukan penerjemahan bebas. Di mana dalam bahasa sasaran verba pull diterjemahkan menjadi diliputi yang memiliki makna yang lebih sesuai dengan konteksnya. Di sini terjadi pergeseran makna yaitu verba pull mengalami perluasan makna menjadi diliputi. Walaupun penerjemah melakukan penerjemahan bebas, tidak mengurangi makna yang sebenarnya.

\section{Verba Pull + Partikel Adverbia}

1a: A large fountain was lit up with blue lights outside the main entrance and to her annoyance everybody on the bus cheered once again when they pulled outside. (PSILY Chapter 27 page 167)

1b: Di luar pintu masuk utama, tampak air mancur dihiasi lampu-lampu biru, dan hatinya kesal bukan main waktu seisi bus lagi-lagi bersorak saat mereka berhenti persis di depan hotel. (PSILYT Chapter 27 page 320) 
Analisis:

Secara sintaksiss, verba pull 1a pada data diatas merupakan verba bentuk past tense. Past tense digunakan untuk menyatakan suatu perbuatan yang terjadi pada waktu lampau.Pull daalah kata kerja beraturan sehingga bentuk lampaunya hanya ditambah -ed. Dalam kalimat 1a terdiri dari tiga klausa dan verba pull terdapat dalam klausa ketiga. Bentuk pull pada 1a di sini adalah verba intransitive karena tidak memiliki objek. Verba pull pada 1a diikuti partikel up yang merupakan satu kesatuan yang tidak dapat dipisahkan. Kata up di sini adalah partiel adverbia yang mengacu pada verbanya yaitu pull yang membentuk verba frasal. Dalam bahasa sumber verba pull up berbentuk verba frasal sedangkan dalam bahasa sasaran berbentuk kata yaitu berhenti. Secara sintaksis terjadi pergeseran tataran di mana verba pull dalam bahasa sumber adalah frase berubah menjadi kata dakam bahasa sasaran.

Untuk membuktikan up adalah artikel adverbia dari pull yang membentuk verba frasal maka dilakukan analisis wh-question:

... they pulled up outside.

Where did they pull up? - outside

Up where did they pull? - tidak diterima

Secara semantis, makna leksikal pull adalah menarik, sedangkan makna up adalah ke atas, ke,dannaik. Kombinasi verba + partikel adverbia pull up dalam bahasa sasaran tidak diterjemahkan dalam masing-masing makna leksikal. Verba frasal pull up pada 1a secara leksikal bermakna "(of a vehicle orits driver) to stop." Penerjemah menghasilkan makna leksikal yakni frasapullup dalam kalimat tersebut dierjemahkan menjadi berhenti. Pada kalimat di atas tidak terjadi pergeseran pada tataran semantis karena dalam bahasa sumber maupun sasaran pull memiliki makna yang sama.

2a: With that, Ciara stood up at the table and pulled down her trousers, revealing a butterfly on her behind. (PSILY Chapter 7 page 41)

2b: Yanpa ba-bi-bu lagi. Ciara langsung berdiri dan memelorotkan celana panjangnya, menunjukkan tato kupu-kupu di bokongnya.(PSILYT Chapter \& page 72)

Analisis:

Secara sintaksis verba pull pada 2 a di atas merupakan verba bentuk past tense. Past tense digunakan untuk menyatakan suatu perbuatan yang terjadi pada waktu lampau.Pull adalah kata kerja bentuk beraturan sehingga bentuk lampaunya hanya ditambah -ed. Dalam kalimat tersebut terdiri atas dua klausa dan verba pull terdapat dalam klausa ke dua. Bentuk pull pada $2 \mathrm{a}$ di sini adalah verba transitif karena memiliki objek berupa nomina yaitu her trousers. Kata down disini adalah partikel adverbia yang lebih mengacu pada verb-nya yaitu pull yang membentuk frasa verba. Secara sintaksis terjadi pergeseran tataran yakni 
verba pull dalam bahasa sumber adalah frase berubah menjadi kata dalam bahasa sasaran, walaupun fungsi dari bahasa sumber ke bahasa sasaran adalah sama yaitu sebagai predikat. Untuk membuktikan down adalah partikel adverbia dari pull yang membentuk frasa verba maka dilakukan wh-question.

Ciara pulled down her trousers.

What did Ciara pulled down? - her trousers

Down what Ciara pull? - tidak diterima

Secara semantis, makna leksikal pull adalah menarik sedangkan makna down adalah (di/ke) bawah, merosot,turun, atau sampai kepada. Kombinasi verba + partikel adverbia pull down dalam bahasa sasaran tidak terjemahkan dalam masing -masing makna leksikal. Penerjemah melakukan penerjemahan bebas karena verba frasal pull down dalam kalimat tersebut diterjemahkan menjadi makna kontekstual yaitu memelorotkan. Kombinasi verba pull dan down memiliki makna kelsikal "to destroy a building completely." Dalam kalimat 2b terjadi pergeseran makna yaitu verba pull mengalami perubahan makna (makna khususs) menjadi memelorotkan. Dimana dalam bahasa sasaran verba pull diterjemahkan menjadi memelorotkan yang memiliki makna lebig sesuai berdasarkan konteksnya. Walaupun penerjemahan melakukan penerjemahan bebas akan tetapi tidak mengurangi makna yang sebenarnya.

\section{PENUTUP}

\section{Simpulan}

Dari hasil pembahasan, penulis dapat menyimpulkan sebagai berikut.

1. Secara sintaksis, verba pull dapat diikuti unsur yang berbeda-beda. Dalam novel P.S. I Love You karya Cecilia Ahern ditemukan verba pull yang diikuti unsur-unsur seperti:

1) Pull + objek

2) Pull + preposisi

3) Pull + partikel adverbia

2. Secara sintaksis dari data yang penulis analisis, kebanyakan terjadi pergeseran tataran ketika verba pull diikuti oleh partikel adverbia yaitu dalam bahasa sumber adalah frase berubah menjadi kata dalam bahasa sasaran. Dalam novel tersebut paling banyak kata bentuk lampau sehingga variasi penggunaan kata yang berbeda jaarang sekali ditemukan.

3. Dari data yang penulis analisis secara semantis, penulis menemukan beberapa pergeseran makna seperti adanya perluasan maknadan penambahan makna. Dalam penerjemahan, yang digunakan untuk menerjemahkan bahasa sumber ke bahasa 
sasaran penerjemah banyak menghasilkan makna leksikal dan beberapa makna kontekstual.Ada pula yang menghasilkan beberapa penerjemahan bebas.

\section{Saran}

Setelah menganalisis mengenai verba pull dalam novel PS I Love You karya Cecilia Ahern dan terjemahannya secara sintaksis dan semantis, penulis dapat mengambil beberapa gambaran mengenai hal-hal yang harus diperhatikan apabila seseorang hendak menerjemahkan sesuatu dari bahasa sumber ke bahasa sasaran. Seorang penerjemah harus mempunyai kemampuan untuk membuat suatu terjemahan yang baik dan sesuai dengan maksud yang disampaikan oleh bahasa sumber.Jangan sampai pesan yang sebenarnya ingin disampaikan oleh penulis tidak dapat tersampaikan dengan baik oleh si penerjemah. Maka si pembaca yang akan dirugikan karenanya.

Pengetahuan umum si penerjemah dan latar belakang pendidikan mengenai hal penerjemahan juga sangat mendukung dalam hasil penerjemahannya. Tidak semua hasil penerjemahan akan sama seratus persen dari bahasa sumber ke bahasa sasaran, tetapi pergeseran suatu kata, frasa, klausa, kalimat atau wacana dapat dibenarkan asal sesuai dengan konteks kalimatnya. Selain itu, pesan yang ingin disampaikan dapat dimengerti oleh si pembaca dengan baik. 


\section{DAFTAR PUSTAKA}

Catford, J. C. 1965. A Linguistic Theory of Translation. London: Oxford University Press.

Chaer, Abdul. 2003. Linguistik Umum. Jakarta: Rineka Cipta.

2003. Linguistik Umum. Jakarta: Rineka Cipta.

Echols M. John and Shadily Hassan. 1992. Kamus Inggris - Indonesia. Jakarta: PT Gramedia Pustaka Utama.

Hornby, A. S. 1975. Guide to Patterns and Usage in English. London: Oxford University Press.

2000. Oxford Advance Lerarner's Dictionary of Current English. London: Oxford University Press.

House, Hormen and Harman, Susan. 1950. Descriptive English Grammar. Englewood Cliffs New Jersey: Prentice-Hall, Inc.

Jacobs, Roderick A. 1995. English Syntax: A Grammar for English Language Professionals. London: Oxford University Press.

John, Meliie, Paulene M. Yates \& Edward N. De Laney.1982.Basic Language, Message and Meaning IV. USA: Harper and Row Publisher INC.

Kridalaksana, Harimurti. 1994. Kelas Kata dalam Bahasa Indonesia. Jakarta: PT Gramedia Pustaka.

Leech, Geoffrey. 1989. An A-Z English Grammar and Usage in English. London: Oxford University Press.

Murphy, Raymond. 1987. Engkkish Grammar in Use. USA: Cambridge University Press.

Nababan, Rudolf. 1999. Teori Menerjemahkan Bahasa Inggris. Yogyakarta: Pustaka Pelajar.

Newmark, Peter. 1988. A Text Book of Translation. Hertfordshire: Prentice Hall International Ltd. 
O’Grady William. 1997. Contemporary Linguistic. London \& New York: Longman.

Quirk, Randolph, et al. 1985.A Comprehensive Grammar of The English Language. New York: Longman Group Limited.

Quirk, Randolph and Greenbaum Sidney. 1973. A University Grammar of English. London: Longman Publisher.

Richard, Jack, et al. 1976. Longman Dictionary of Applied Linguistic. England: Longman Group Ltd.

Swan, Michael. 1995. Practical English Usage. Hongkong: Oxford University Press.

Verhaar. 2001. Asas-Asas Linguistik Umum. Yogyakarta: Gajah Mada University Press. 